\title{
UPPER CAMBRIAN ACRITARCHS FROM BORING CORE M-72 OF NORTH ESTONIA
}

Abstract. Upper Cambrian acritarchs from the borehole M-72, North Estonia, have been described. Six samples from the depth interval $112.8-119.6 \mathrm{~m}$ yielded an acritarch assemblage which can be tentatively correlated to Parabolina spinulosa and/or Leptoplastus Trilobite Zone. Two new species, Cymatiogalea dentalea sp. n. and C. wironia sp. n., have been described.

The present paper is a preliminary account on the acritarchs recovered from a part of the so-called "Obolus sandstone" of North Estonia. The material was collected by the author in 1990 from boring core M-72 about $30 \mathrm{~km}$ south-east of Tallinn. The assemblage of acritarchs contains well-known Upper Cambrian species as well as some new ones.

Material and methods. Six samples were taken from the depth of 112.8$119.6 \mathrm{~m}$ (Fig.). They all, except A-0838, come from very thin browncoloured organic-rich clay interbeds and contain a rich and well preserved assemblage of acritarchs. For maceration HF acid was used; acritarchs were separated with heavy liquid $\left(2.10 \mathrm{~g} / \mathrm{cm}^{3}\right)$ as well as by sieving (mesh diameter $15 \mu \mathrm{m}$ ).

The slides are deposited in the collection of the Geological Museum of Tartu University.

Lithology. The investigated interval of the section overlies the Lower Cambrian Tiskre Formation and underlies the Maardu Member (?Upper Cambrian or Tremadoc) and is represented by grey fine-grained sandstone with thin $(1-3 \mathrm{~cm})$ interbeds of brown organic-rich clay. The sandstone contains abundantly fine debris and complete valves of inarticulate brachiopods. By Popov and Khazanovich, this interval in boring core M-72 belongs to the Tsitre Formation (Опорные..., 1989).

Palaeontology and biostratigraphy. Generally, the assemblage recorded from the investigated samples is uniform consisting of the following species: Actinotodissus sp., Cristallinium sp., Cymatiogalea wironia sp.n., C. dentalea sp. n., C. aff. virgulta Martin, Cymatiogalea sp. 1, Cymatiogalea sp. 2, Cymatiogalea sp. 3, Goniosphaeridium aff. tuberatum (Downie) Wolf, G. aff. dentatum (Timofeev) Rauscher, Goniosphaeridium sp., ?Goniosphaeridium sp., Impluviculus sp., Leiofusa stoumonensis Vanguestaine, Dasydiacrodium caudatum Vanguestaine, D. obsonum Martin, Stelliferidium cortinulum (Deunff) Deunff, Gorka, Rauscher, S. aff. pseudoornatum Pittau, Timofeevia phosphoritica Vanguestaine, $T$. estonica Volkova, Trunculumarium revinium (Vanguestaine) Loeblich et Tappan, Trunculumarium aff. revinium (Vanguestaine) Loeblich et Tappan, Veryhachium dumontii Vanguestaine, Vulcanisphaera turbata Martin, Vulcanisphaera sp.

* Tartu Ulikooli geoloogia kateeder (Department of Geology, Tartu University). Vanemuise 46, Tartu 202400. Estonia. 
This assemblage indicates certainly the Upper Cambrian age of the studied deposits. T. revinium, $D$. caudatum, $V$. dumontii, and L. stoumonensis were first described in the Revinian from Belgium (Vanguestaine, 1973 ). Besides, $T$. revinium and $L$. stoumonensis have a restricted stratigraphical range in Newfoundland. The first appearance of $T$. revinium was recorded in the upper part of the Parabolina spinulosa Zone and disappearance in the lower part of the Peltura Zone. In the same area $L$. stoumonensis had already appeared in the Olenus Zone and its last representatives are found in the top of the Leptoplastus Zone (Martin

? GOWIOSPHAERIOIUN SP. CYMATIOSALEA aff. VIRSULTA CYISATIOSALEA WIRONIA CYMATIRESALEA SP. 1 CYMATIOSALEA DEWTALEA CYMATIOSALEA SP. 2 OOAIOSPHAERIDIUM afF. TUBERATUM AASYDIACRODIUM CAUDATUM AASTOLACRODIIIM OBSONUH IMPLUYCULUS SP. LEIOFUSA STOUMOAEASIS STELLIFERIDIUN CORTINULUY STELLIF. aff. PSEUDOORRATUH TINOFEEYIA ESTOKICA TIMOFEFVIA PHQSPHORITICA TRUACULUMSRIUT REMAIUIY VERYHACHUY OUMONII VULCANISPHAERA TURBATA GOMDSPASERIDIUN SP. 1 CYMATIGALEN SP. 3 CRISTALLIAILIY SP ACTIMDTODISSUS SP. TSITRE FM.

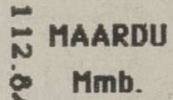
FM.
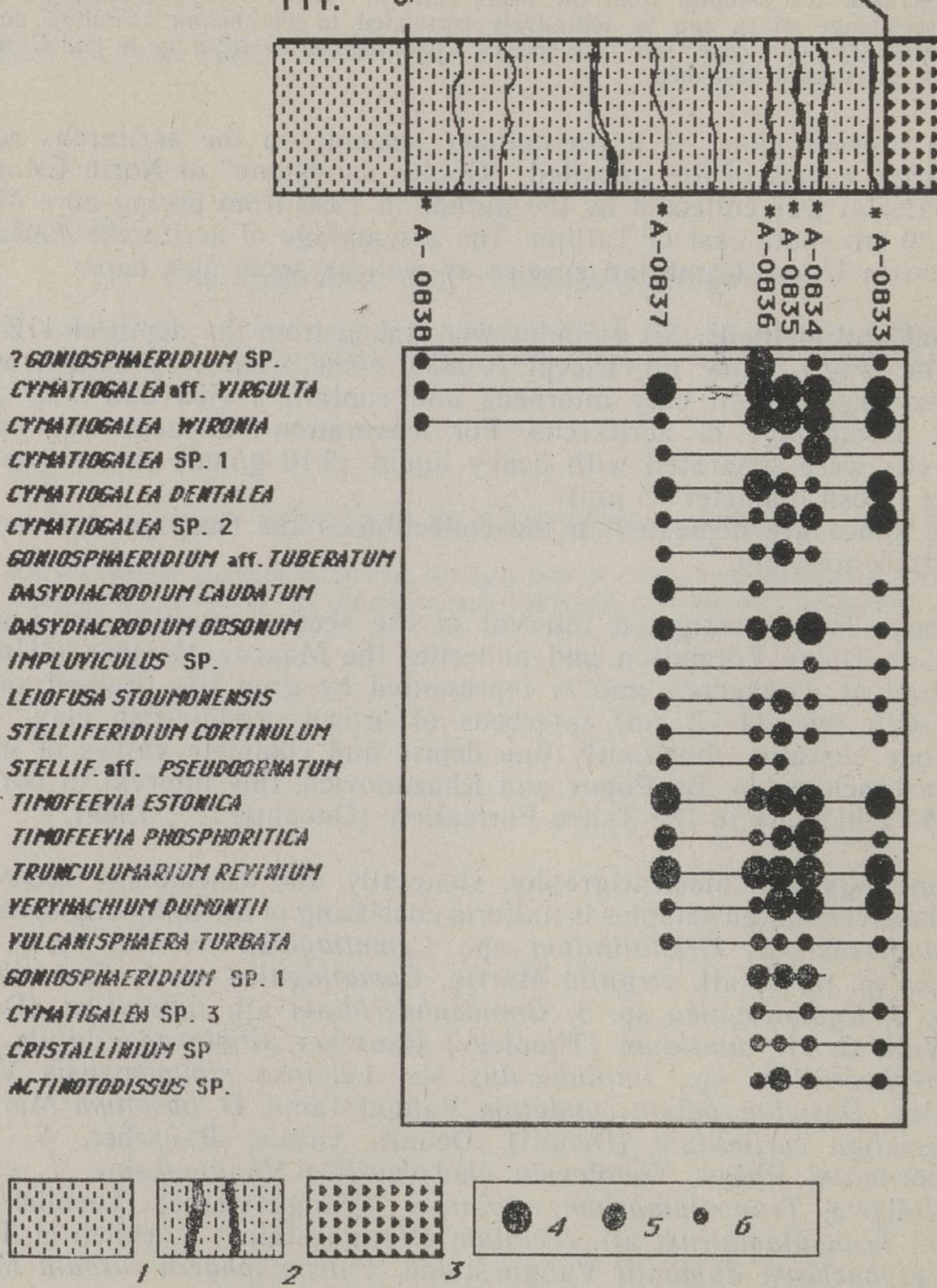

Distribution of the most important acritarch species in the Tsitre Formation, boring core M-72. 1 - siltstone; 2 - sandstone with clay interbeds; 3 - Obolus conglomerate; 4 - over $5 \%$ in sample; $5-1-5 \% ; 6-$ less than $1 \%$. 
and Dean, 1988). In general, the assemblage of acritarchs from the Tsitre Formation has similarity with microflora A4 (= Trunculumarium revinium - Dasydiacrodium caudatum assemblage) from the Elliot Cove Formation in eastern Newfoundland. The latter corresponds to the upper part of the Parabolina spinulosa Zone and almost to the whole Leptoplastus Zone (Martin and Dean, 1988). Volkova (Волкова, 1990) determined a similar assemblage of acritarchs in boring core $M-9$ (interval $134.5-146.0 \mathrm{~m}$ ), at the time of sampling considered the Ulgase Formation. On the basis of new data, Popov and Khazanovich (Опорные..., 1989) referred this interval to the Tsitre Formation and correlated it with the upper part of the Parabolina spinulosa Zone and lower part of the Leptoplastus Zone. Accordingly, the assemblage of acritarchs derived from the Tsitre Formation in boring core $M-72$ may occur in the upper part of the Parabolina spinulosa Zone and/or in the Leptoplastus Zone.

\section{Systematic descriptions of acritarchs}

Abbreviations. $D_{v}$ - diameter of vesicle; $L_{v}$ - length of vesicle; $B_{v}$ breadth of vesicle; $L_{p}$ - length of processes; $B_{b}$ - basal breadth of process; $N_{p}$ - number of processes; $D_{p f}$ - diameter of polygonal field; $D_{p}$ - diameter of pylom.

Genus Cymatiogalea Deunff, 1961, emend. Deunff, Gorka, Rauscher, 1974

Remarks. The species of the genus Cymatiogalea of the Tsitre Formation typically occur in great abundance and have wide variability. The variability is best expressed in the morphology of processes and in the number and configuration of polygonal fields. So, on the basis of morphology four types of processes can be distinguished:

(a) small, conical, nonfurcated, knob-like processes, formally C. cuvillieri type (Pl. 1, figs. 1 and 2);

(b) cylindrical, distally nonfurcated or furcated to the first order processes, formally $C$. virgulta type (P1. 1, fig. 4);

(c) cylindrical, distally furcated from the second to the fourth order processes, formally $C$. aspergillum type (Pl. 1, figs. 2 and 5);

(d) cylindrical processes, distally furcated and connected with each other by weils, formally $C$. velifera type (Pl. 1, fig. 6).

By the configuration and number of polygonal fields two formal groups can be distinguished:

(a) specimens with quadrangular fields. Using the formula of tabulation proposed by Rasul (1974) for the genus Cymatiogalea, it is $1: 4: 1$ (Pl. 1, figs. 1 and 2).

(b) specimens with combinations of pentagonal and hexagonal fields. The formula of tabulation is variable, being usually $1: 5: 6: 1,1: 6: 5: 1$, $1: 5: 2$.

At present, the importance of such features as configuration of fields and formula of tabulation is unclear because no survey of the variation of these features in time exists.

\section{Cymatiogalea dentalea sp. n.}

P1. 1, fig. 1

Material. Over 200 specimens.

Holotype. P1. 1, fig. 1; prep. S/12 IIB25.

Type locality. Boring core M-72, depth 113.9, North Estonia.

Derivation of name. Latin, dentis $=$ tooth. 
Diagnosis. Vesicle originally globular, with circular outline. Homomorphic, little knob-like nonfurcated processes are placed regularly and divide the vesicle into quadrangular polygonal fields. The distal parts of processes are blunt, the proximal parts are widened and have curved contacts with vesicle. The bases of processes bear ray-like folds. Interior of processes is solid. The formula of tabulation is $1: 4: 1$. Four to five processes occur on each edge of the field. The total number of processes on the vesicle ranges from 20 to 26 .

Excystment-pylom, with simple undecorated collar or without collar. Operculum has a quadrangular or subquadrangular configuration. Surface of the vesicle and the operculum is uniform, rugulate.

Dimensions. $D_{v}-20-27$ (25.5) $\mu \mathrm{m} ; L_{p}-1.0-3.5$ (2.3) $\mu \mathrm{m} ; D_{p f}-$ $10.0-17.5(15.0) \mu \mathrm{m} ; B_{b}-1.8-2.5(2.3) \mu \mathrm{m} ; D_{p}-10.0-16.0$ (14.5) $\mu \mathrm{m}$. Comparison. C. dentalea sp. n. differs from C. cuvillieri (Deunff) and C. multarae (Deunff) in a different number and configuration of fields, as well as in the morphology of appendixes.

Occurrence. Tsitre Formation, upper part of $P$. spinulosa Zone and/or Leptoplastus Zone, Upper Cambrian, North Estonia.

\section{PLATE 1}

Scale bar: 10 microns for all figures.

Fig. 1. Cymatiogalea dentalea sp. n.; (holotype), sample A-0834, prep. S/12 IIB25. Fig. 2. Cymatiogalea wironia sp. n.; (holotype), sample A-0834, prep. S/12 IIB18. Fig. 3. Cymatiogalea sp. 1; sample A-0834, prep. S/12 IIE12. Fig. 4. Cymatiogalea aff. virgulta Martin; sample A-0834, prep. S/12 IIB12. Fig. 5. Cymatiogalea sp. 2; sample A-0834, prep. S/12 IIC2. Fig. 6. Cymatiogalea sp. 3; sample A-0834, prep. S/12 IIC25.

\section{PLATE 2}

Figs. 1, 2. Trunculumarium aff. revinium (Vanguestaine) Loeblich et Tappan; sample A-0834, 1 - prep. S/12 IIB23; 2 - prep. S/12 IIB11. Figs. 3, 4. Trunculumarium revinium (Vanguestaine) Loeblich et Tappan; sample A-0834; 3 - prep. S/12 IIB6, 4 - prep. S/12 IIB15. Fig. 5. Dasydiacrodium caudatum Vanguestaine; sample A-0834, prep. S/12 IID11. Fig. 6. Veryhachium dumontii Vanguestaine; sample A-0834, prep. S/12 IIB13.

\section{PLATE 3}

Figs. 1, 2. Trunculumarium aff. revinium (Vanguestaine) Loeblich et Tappan; slide A-0834. Figs. 3, 4. Trunculumarium revinium (Vanguestaine) Loeblich et Tappan; slide A-0834. Figs. 5-8. Veryhachium dumontii Vanguestaine; slide A-0834. Fig. 9. Goniosphaeridium sp.; slide A-0834. Fig. 10. Actinotodissus sp; slide A-0834. Fig. 11. Dasydiacrodium obsonum Martin; slide A-0834.

\section{PLATE 4}

Fig. 1. Goniosphaeridium sp.; slide A-0834. Fig. 2. Leiofusa stoumonensis Vanguestaine; sample A-0834, prep. S/12 IIB7. Fig. 3. ?Goniosphaeridium sp.; slide A-0834. Fig. 4. Goniosphaeridium sp.; sample A-0834, prep. S/12 IID32. Fig. 5. Cristallinium sp.; sample A-0834, prep. S/12 IID21. Fig 6. Vulcanisphaera aff. africana Deunff; sample A-0834, prep. S/12 IIE8.

\section{PLATE 5}

Fig. 1. Vulcanisphaera turbata Martin; sample A-0834, prep. S/12 IIB24. Fig. 2. Actinotodissus sp.; sample A-0834, prep. S/12 IIC26-3. Fig. 3. Timofeevia phosphoritica Vanguestaine; sample A-0837, prep. S/12 IIF9. Fig. 4. Timofeevia estonica Volkova; sample A-0834, prep. S/12 IIB8. Fig. 5. Impluviculus sp.; sample A-0837, prep. S/12 IIF14. Fig. 6. Dasydiacrodium obsonum Martin; sample A-0834; prep. S/12 IID28.

PLATE 6

Figs. 1-2. ?Goniosphaeridium sp.; sample A-0834, 1 - prep. S/12 IIB12; 2 prep. S/12 IIC14. Fig. 3. Goniosphaeridium aff. dentatum; sample A-0834, prep. S/12 IID9. Fig. 4. Goniosphaeridium aff. tuberatum; sample AA-0834, prep. S/12 IIC8. Fig. 5. Stelliferidium aff. pseudoornatum Pittau; sample A-0834, prep. S/12 IIC18. Fig. 6. Stelliferidium cortinulum (Deunff); sample A-0834, prep. S/12 IIB20. 

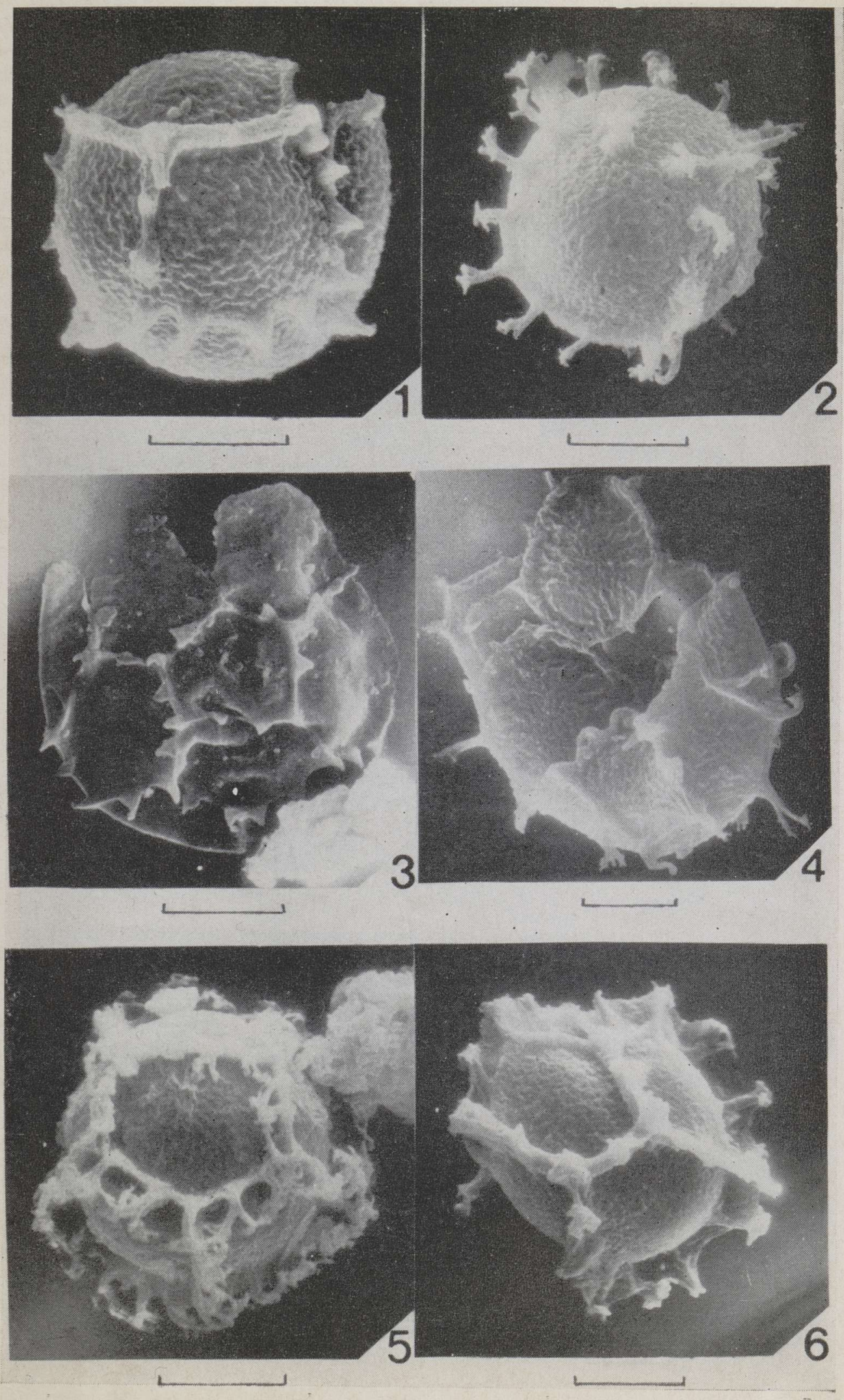

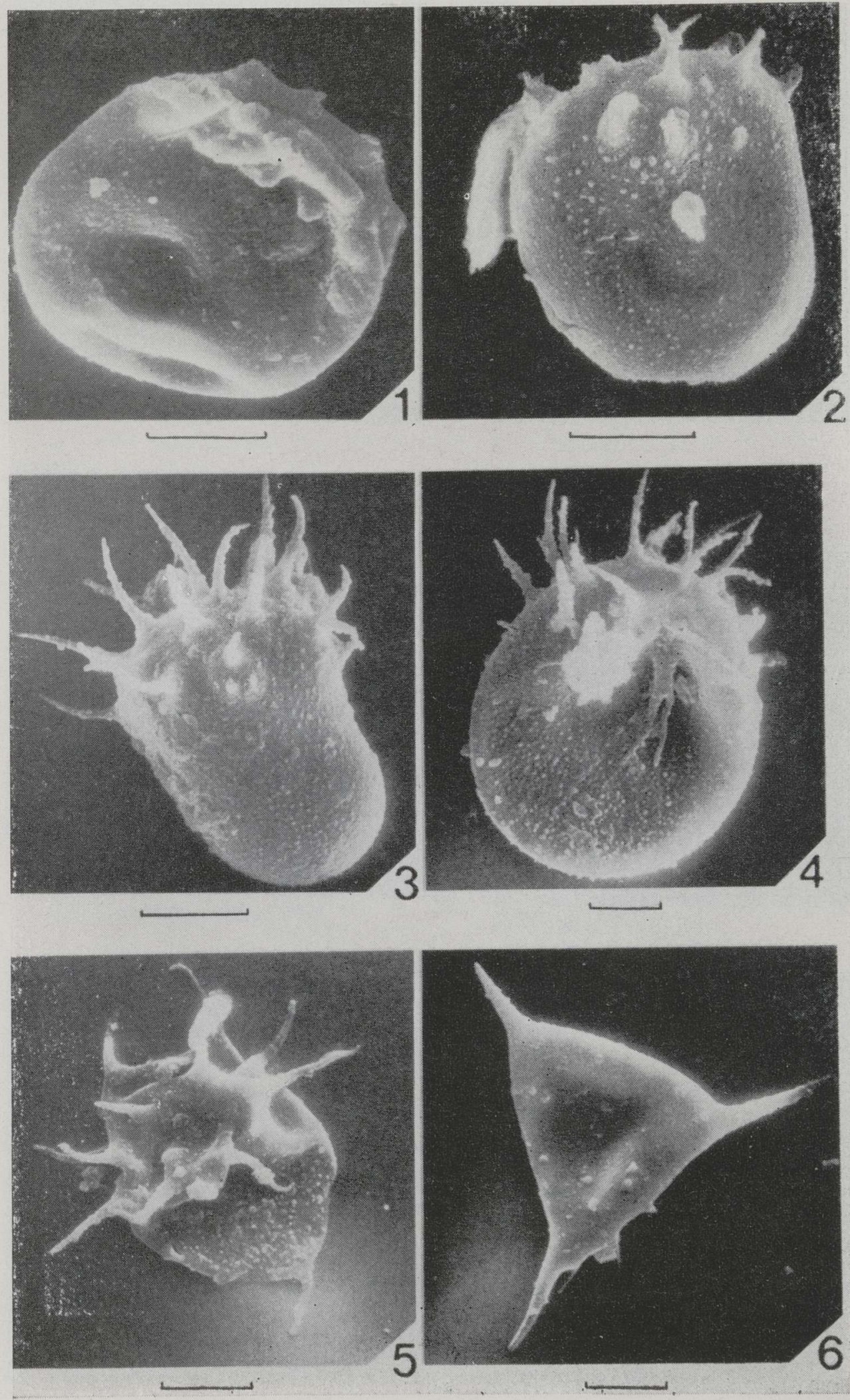

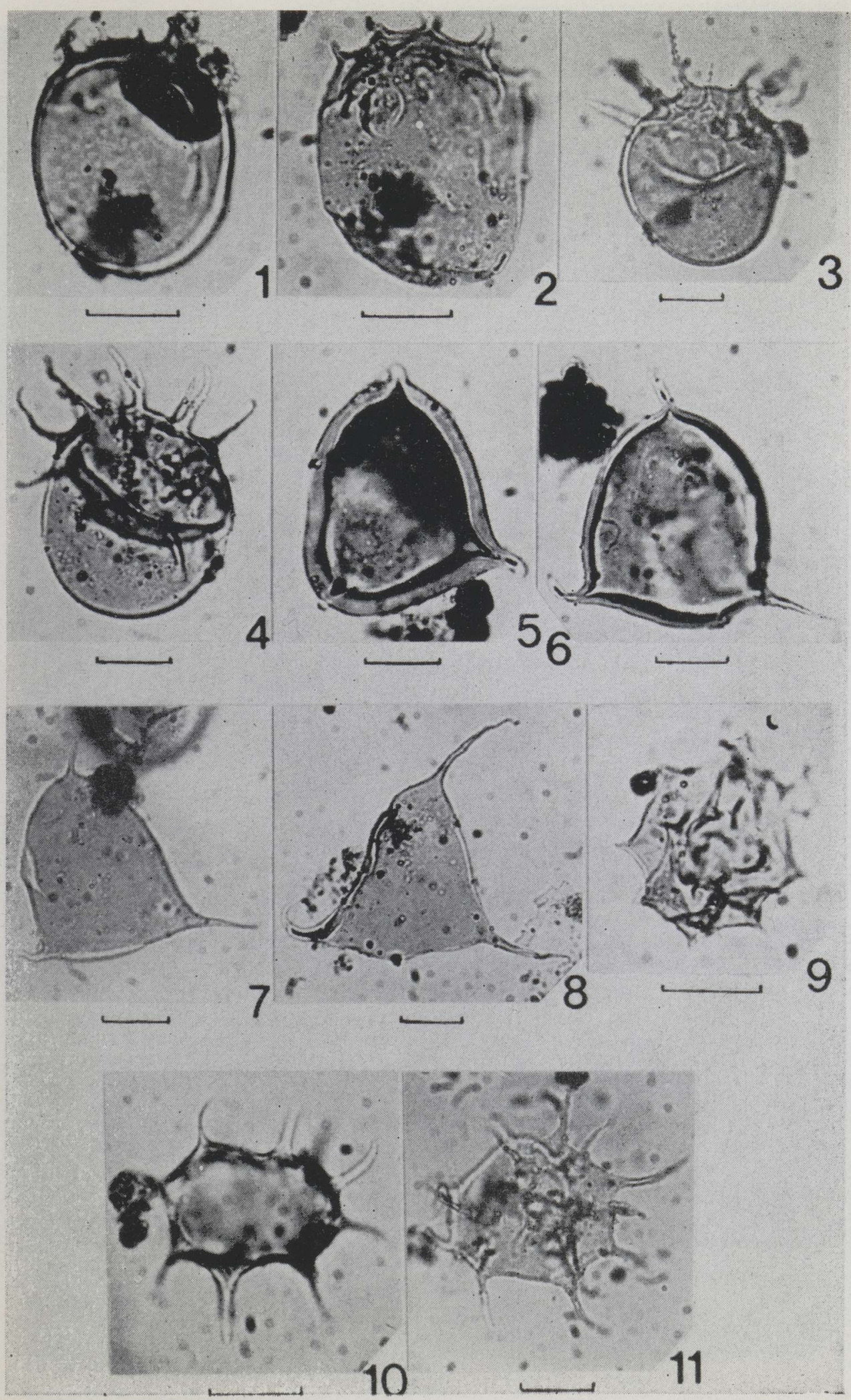
PLATE 4
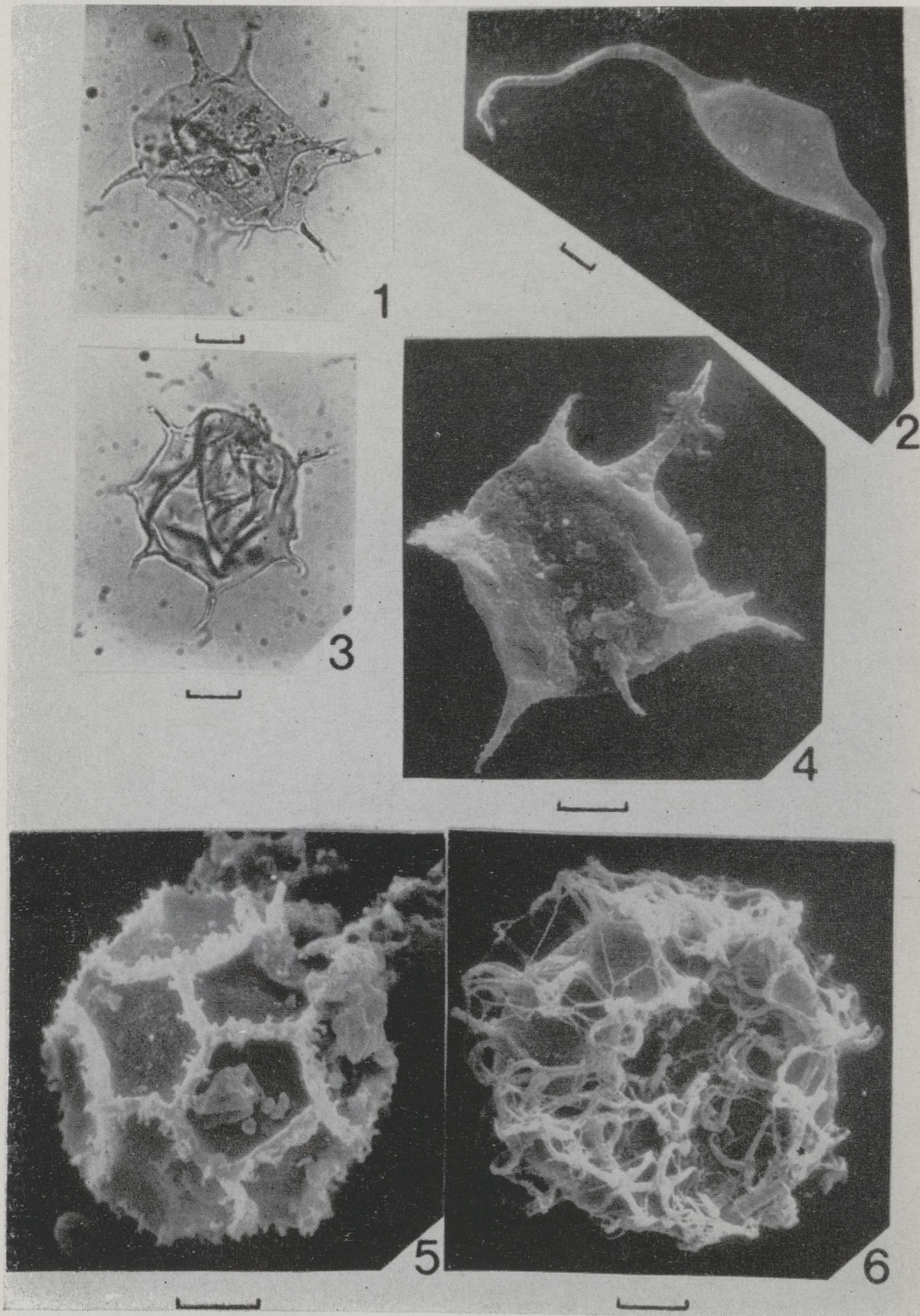

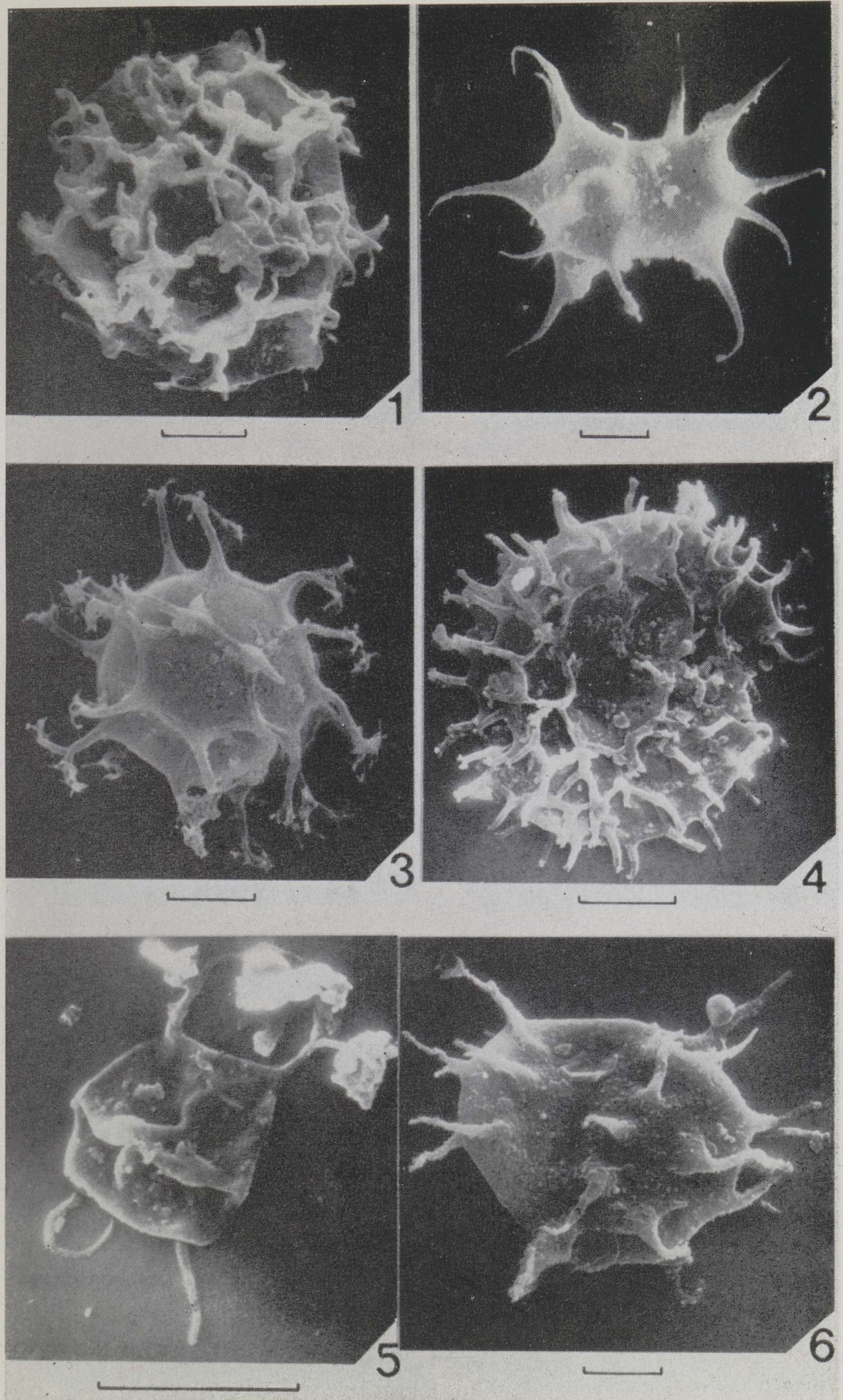
PLATE 6
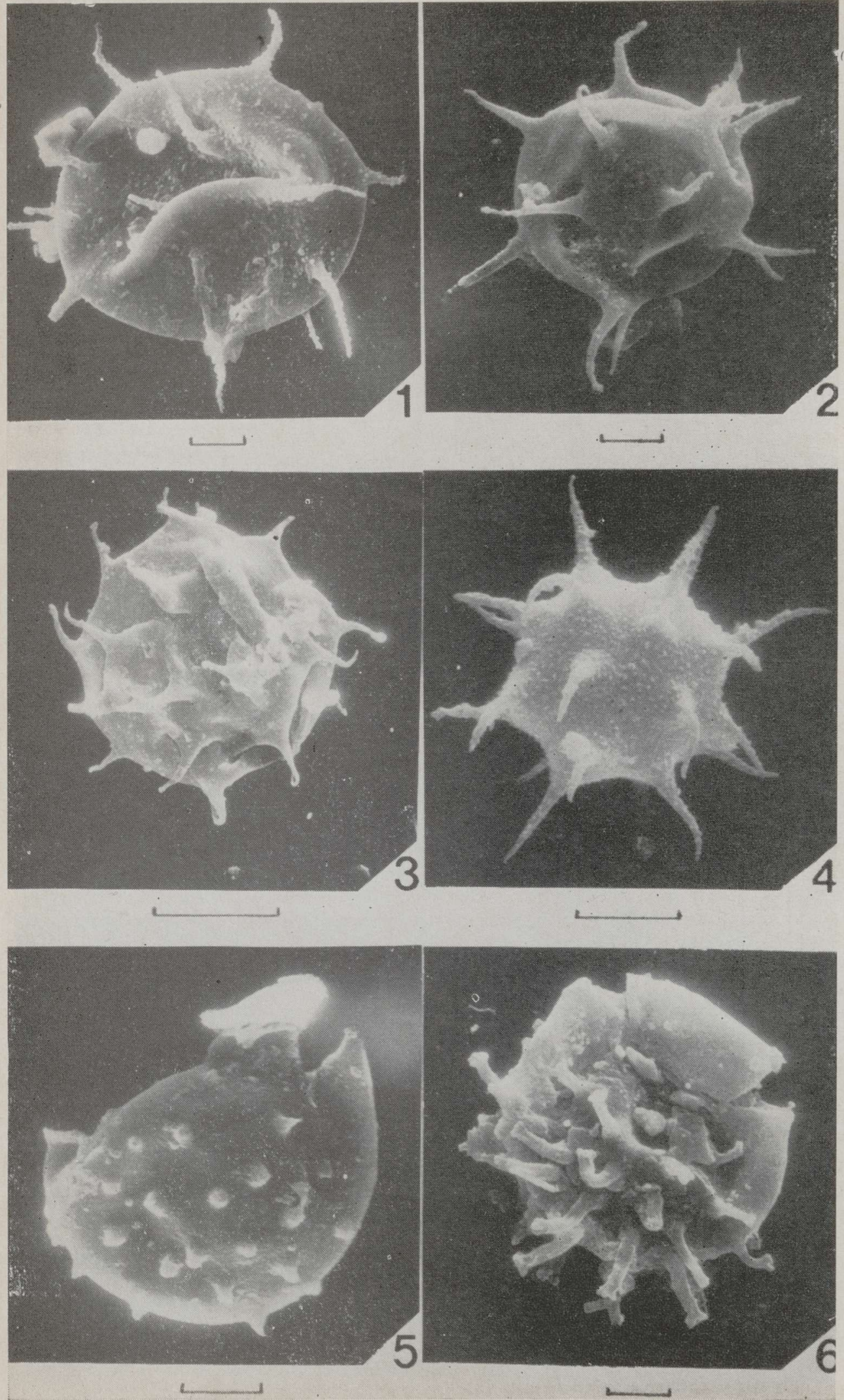

$$
2
$$


Material. Over 300 specimens.

Holotype. Pl. 1, fig. 2; prep. S/12 IIB18.

Type locality. Boring core M-72, North Estonia.

Derivation of name. Wironia is the old name of North Estonia.

Diagnosis. Vesicle originally globular, with circular outline. Heteromorphic, slender processes are placed regularly in rows and divide the vesicle into polygonal fields of quadrangular configuration. The distal parts of processes are nonfurcated with blunt tips or furcated to the first and second order. The proximal parts of processes are widened and have curved contacts with vesicle. The bases of processes are ornamented with ray-like folds. The interior of processes is solid or hollow (with trabeculas) without free connection with the vesicle cavity. Edges of the field are marked by three to four processes. The total number of processes on the vesicle is from 20 to 25 .

Excystment-pylom, decorated with little nonfurcated processes.

Operculum has a quadrangular or rounded configuration. The surfaces of the vesicle and operculum are uniform, rugulate.

Dimensions. $D_{v}-23.0-28.5$ (25.4) $\mu \mathrm{m} ; L_{p}-4.5-8.5 \quad$ (5.5) $\mu \mathrm{m}$; $D_{p f}-12.5-17.0(14.0) \mu \mathrm{m} ; B_{b}-1.3-2.0(1.8) \mu \mathrm{m} ; D_{p}-12.5-16.5$ (13.5) $\mu \mathrm{m}$.

Comparison. C. wironia sp. n. has a construction of processes similar to C. virgulta Martin described from the Elliot Cove Formation (Martin and Dean, 1988) but differs in the number of polygonal fields.

Occurrence. Tsitre Formation, upper part of $P$. spinulosa Zone and/or Leptoplastus Zone, Upper Cambrian, North Estonia.

Genus Dasydiacrodium Timofeev, 1959 ex. and emend. Deflandre and Deflandre-Rigaud, 1962

Dasydiacrodium caudatum Vanguestaine, 1973

P1. 2, fig. 5

Dasydiacrodium caudatum sp. n.; Vanguestaine, 1973, p. 30; P1. 1, Figs. 9 and 13.

D. caudatum Vanguestaine; Martin and Dean, 1981, p. 18, Pl. 1, Figs. $10,11,15$.

Material. 45 specimens.

Description. Vesicle triangular or suboval in outline. On the antapex carries a single nonfurcated, conical process with acuminated top having curved contact with the vesicle. The apex bears from 10 to 15 irregularly placed nonfurcated conical processes which are widened in the basal part and have a transitional contact with the vesicle. The interior of the processes is hollow to $2 / 3$ of the extent and has a free communication with the vesicle cavity. The surface of the vesicle is covered with little spines.

Excystment mechanism absent.

Dimensions. $L_{v}-20-26$ (24) $\mu \mathrm{m} ; B_{v}-17-21$ (19) $\mu \mathrm{m} ; L_{p}-2.5-10$ (7.5) $\mu \mathrm{m} ; N_{p}-8-15$ (13).

Occurrence. Tsitre Formation, upper part of $P$. spinulosa Zone and/or Leptoplastus Zone, Upper Cambrian, North Estonia; Upper Cambrian; from Revinian ( $\mathrm{Rn} 2 \mathrm{~b}$ ) in Stavelot area to Belgium (Vanguestaine, 1973); upper part of the Elliot Cove Formation from the Parabolina spinulosa Zone to the Peltura Zone and Clarenville Formation from Newfoundland (Martin and Dean, 1981). 
Dasydiacrodium obsonum sp. n.; Martin and Dean, 1988, p. 38, P1. 10, figs. $6,7,10,13-15$.

Material. 67 specimens.

Description. Vesicle with elongated polygonal configuration. The poles of the vesicle are covered with conical nonfurcated processes. The number of processes on the poles ranges from 6 to 20 , the total number of processes on the vesicle from 16 to 26 . These have curved contact with vesicle and the interior of the processes is hollow to $2 / 3$ of the extent with a free communication with the vesicle cavity.

The surfaces of the vesicle and processes are uniform and covered with little spines.

Excystment not observed.

Dimensions. $L_{v}-27-35$ (31.5) $\mu \mathrm{m} ; B_{v}-11.0-21.0 \quad(17.0) \mu \mathrm{m}$; $B_{v \max }-22.0-32.0(27.5) \mu \mathrm{m} ; L_{p}-9.5-14.5(12.0) \mu \mathrm{m} ; B_{b}-1.8-2.6$ (2.1) $\mu \mathrm{m}$.

Occurrence. Tsitre Formation, upper part of $P$. spinulosa Zone and/or Leptoplastus Zone, Upper Cambrian, North Estonia. Elliot Cove Formation, upper part of $P$. spinulosa Zone to Acerocare Zone, Random Island (Martin and Dean, 1988).

Genus Goniosphaeridium Eisenack 1969, emend. Martin, 1972 Goniosphaeridium sp.

Pl. 4, figs. 1 and 4

Material. 85 specimens.

Description. Vesicle with polygonal outline and ornamented with homomorphic conical irregularly placed processes. The distal parts of the processes are nonfurcated with acuminated tips; the proximal parts are widened and have transitional contact with the vesicle. The interior of the processes is hollow to the full extent and has a free communication with the vesicle cavity. The total number of processes is from 8 to 18 .

The surfaces of the vesicle and processes are uniform and covered with little spines.

Excystment not observed.

Dimensions. $D_{v}-34.0-48.5(40.5) \mu \mathrm{m} ; L_{p}-14.0-22.0$ (18.0) $\mu \mathrm{m}$; $B_{b}-4.5-6.5$ (5.1) $\mu \mathrm{m} ; N_{p}-8-18$ (12).

Remarks. Goniosphaeridium sp. has some similarity with ? Goniosphaeridium sp. occurring in the same level, first of all in dimensions, the number of processes, and the surface morphology, but differs in the morphology of the processes and in the configuration of the vesicle. In the investigated material some specimens transitional between these two species were found.

Occurrence. Tsitre Formation, upper part of $P$. spinulosa Zone and/or Leptoplastus Zone, Upper Cambrian, North Estonia.

\section{? Goniosphaeridium sp.}

Pl. 4, fig. 3; Pl. 6, figs. 1 and 2

Material. 105 specimens.

Description. The vesicle is globular, originally with circular or elliptical outline, covered with rare irregularly placed nonfurcated homomorphic processes with acuminated tips. The proximal parts of the processes are a little widened and have a curved contact with the vesicle. The 
interiors of most of the processes are hollow to the full extent and have a free communication with the vesicle cavity. Some processes are solid. The surfaces of the vesicle and processes are uniform, covered with spines.

Excystment is absent.

Dimensions. $D_{v}-35.0-45.0$ (39.5) $\mu \mathrm{m} ; L_{p}-8.5-15.5$ (11.5) $\mu \mathrm{m}$; $B_{b}-1.3-3.5(2.4) \mu \mathrm{m} ; N_{p}-12-17$ (14).

Occurrence. Tsitre Formation, upper part of $P$. spinulosa Zone and/or Leptoplastus Zone, Upper Cambrian, North Estonia.

Genus Timofeevia Vanguestaine, 1978

Timofeevia estonica Volkova, 1990

Pl. 5, fig. 4

Timofeevia estonica sp. n.: Волкова, 1990 , p. 84 , Pl. 9, figs. 4 and 5 .

Description. Vesicle originally globular, circular in outline. Covered with numerous processes, over 80 in number. The processes are heteromorphic, cylindrical, distally furcated to the first and second order or nonfurcated with acuminated tips. The bases of the processes are widened. Every process has a connection with three adjacent processes by folds beginning in the proximal part of the process and forming polygonal fields, usually with a pentagonal configuration. The interior of the processes is solid except for the basal part which is hollow and has a free communication with the vesicle cavity. The surfaces of the vesicle and processes are smooth.

Excystment: rupture or pylom-like structure.

Dimensions. $D_{v}-20.5-28.5$ (25.7) $\mu \mathrm{m} ; D_{p f}-4.8-6.5$ (5.7) $\mu \mathrm{m}$; $L_{p}-2.0-6.5$ (4.8) $\mu \mathrm{m} ; B_{b}-0.5-1.5$ (1.1) $\mu \mathrm{m}$.

Occurrence. Tsitre Formation, upper part of $P$. spinulosa Zone and/or Leptoplastus Zone, Upper Cambrian, North Estonia. Ulgase Formation, Olenus Zone and lower part of Parabolina spinulosa Zone, Upper Cambrian, North Estonia (Волкова, 1990).

Genus Trunculumarium Loeblich et Tappan, 1976

Trunculumarium revinium (Vanguestaine) Loeblich et Tappan Pl. 2, figs. 3, 4; Pl. 3, figs. 3, 4

Ooidium revinium nov. sp.; Vanguestaine, 1973; p. 30, P1. 1, Figs. 3-6, 10 , and 14 .

Trunculumarium revinium (Vanguestaine) comb. nov. Loeblich et Tappan, 1976, p. 305.

Trunculumarium revinium (Vanguestaine) Loeblich et Tappan; Martin in Martin and Dean, 1981, p. 22, Pl. 2, Figs. 5, 18; Pl. 5, Figs. 4, 6.

Trunculumarium revinium (Vanguestaine) Loeblich et Tappan; Vanguestaine, 1986, P1. 4, Fig. 20; P1. 5, Fig. 21.

Trunculumarium revinium (Vanguestaine) Loeblich et Tappan; Martin in Martin and Dean, 1988, P1. 15, Figs. 7, 12-20.

Trunculumarium revinium (Vanguestaine) Loeblich et Tappan; Volkova, 1990, p. 88, P1. 22, Figs. 7, 8, 10, 11.

Material. Over 100 specimens.

Description. The outline of the vesicle is oval or subcircular. On one of the poles 9 to 15 homomorphic processes are located. The processes are slender and conical, nonfurcated with acuminated tips, having a curved contact with the vesicle. Most of the processes are solid but they rarely have basic protrusions. The surfaces of the vesicle and processes are covered with spines. 
The excystment opening is absent or is represented by a rupture. Dimensions. $L_{v}-28-37$ (33.1) $\mu \mathrm{m} ; B_{v}-20-30$ (24.6) $\mu \mathrm{m} ; L_{p}-$ 8-17 (11.6) $\mu \mathrm{m} ; B_{b}-1.5-2.5$ (2.0) $\mu \mathrm{m} ; N_{p}-6-14$ (10).

Occurrence. Tsitre Formation, upper part of $P$. spinulosa Zone and/or Leptoplastus Zone, Upper Cambrian, North Estonia. Revinian (Rn 2b), Upper Cambrian, from Stavelot area of Belgium (Vanguestaine, 1973); Elliot Cove Formation, upper part of Parabolina spinulosa Zone and Leptoplastus Zone, Random Island in eastern Newfoundland (Martin and Dean, 1988). Kistedal Formation, Upper Cambrian, Finnmark, North Norway (Welsch, 1986), Bugino Formation, Upper Cambrian, Moscow syneclise (Волкова, 1990).

Genus Veryhachium Deunff, emend. Downie and Sarjeant, 1963 Veryhachium dumontii Vanguestaine, 1973

P1. 2, fig. 6; Pl. 3, figs. 5-8;

V. dumontii sp. n.; Vanguestaine, 1973, p. 28, P1. 1, Figs. 1, 2, 8

V. dumontii; Martin in Martin and Dean, 1981, p. 22, Pl. 1, Figs. 7 and 8 V. dumontii; Martin in Martin and Dean, 1988, p. 41, Pl. 16, Figs. 2, 3, 7, $10-18$.

Material. Over 200 specimens.

Description. The vesicle is triangular in outline with three symmetrically placed main processes. On the antapex there are two homomorphic processes located crosswise to the axis of the vesicle. These are slender, conical, with acuminated tips. The contact with the vesicle is curved. The communication with the vesicle interior is absent or represented only in the basal parts of the processes. The apex bears a single process, similar to the processes on the antapex. In some specimens one to three secondary processes (length $3-6 \mu \mathrm{m}$ ) smaller than the main processes occur. The surfaces of the vesicle and processes are smooth or covered with small spines. The excystment opening is absent or is represented by rupture.

Dimensions. $L_{v}-28-43$ (35) $\mu \mathrm{m} ; B_{v}-20-30$ (24) $\mu \mathrm{m} ; L_{p}-1.5-36$ (9.5) $\mu \mathrm{m} ; B_{b}-2.5-5.5$ (3.0) $\mu \mathrm{m}$.

Variability. $V$. dumontii is a species with a wide range of variability expressed in the length of processes. In the studied material specimens with reduced processes (P1. 1, fig. 5) as well as specimens with processes two times longer than the vesicle are represented.

Occurrence. Tsitre Formation, upper part of Parabolina spinulosa and/or Leptoplastus Zone, North Estonia. Revinian, (Rn 2b), Upper Cambrian from Belgium (Vanguestaine, 1973). Elliot Cove Formation, Upper Cambrian, Newfoundland (Martin and Dean, 1988).

Acknowledgments. I am grateful to Dr. K. Mens and Mrs. A. Noor (Institute of Geology in Tallinn) for comments and for revising the manuscript. Thanks are due to Miss U. Moldov for SEM photos, 


\section{R E F E R E N E S}

Martin, F. and Dean, W. T. 1981. Middle and Upper Cambrian and Lower Ordovician acritarchs from Random Island, eastern Newfoundland. - Geol. Surv. of Canada, Bull. 343, 1-43.

Martin, F. and Dean, W. T. 1988. Middle and Upper Cambrian acritarch and trilobite zonation at Manuels River and Random Island, eastern Newfoundland. - Geol. Surv. of Canada, Bull. 381, $1-91$.

Rasul, S. M. 1974. The Lower Paleozoic acritarchs Priscogalea and Cymatiogalea. Palaeontology, 17, $41-63$.

Vanguestaine, M. 1973. New acritarchs from the Upper Cambrian of Belgium. - Microfossils of the Oldest Deposits; Proceedings of Third International Palynological Conference. Academy of Sciences of the U.S.S.R., 28-30.

Welsch, M. 1986. Die Acritarchen der höheren Digermul Gruppe, Mittelkambrium bis Tremadoc, Ost-Finnmark, Nord-Norwegen. - Palaeontographica, Abt. B, 201, $1-109$.

Волкова Н. А. 1990. Акритархи среднего и верхнего кембрия Восточно-Европейской платформы. Москва, Наука.

Опорные разрезы и стратиграфия кембро-ордовикской фосфоритоносной оболовой толщи на северо-западе Русской платформы. 1989. Ленинград, Наука.

Presented by D. Kaljo

Received

Aug. 19, 1991

Ivo PAALITS

\section{ULEMKAMBRIUMI AKRITARHID PUURSUDAMIKUST M-72 PÕHJA-EESTIST}

Proovid on kogutud Tallinnast $30 \mathrm{~km}$ kagus asuvast puuraugust $\mathbf{M}-72$ sügavuselt 112,8-119,6 m. See vahemik vastab Tsitre kihistule. Kõik viis proovi sisaldasid rikkalikult akritarhe, mis lubavad Tsitre kihistut vaadeldavas läbilöikes korreleerida kas Parabolina spinulosa trilobiidi tsooni ülemise osaga ja/või Leptoplastus'e tsooniga. Lisaks on kirjeldatud kaks uut liiki: Cymatiogalea wironia sp. n. ja C. dentalea sp. n.

Нво ПААЛИТС

\section{АКРИТАРХИ ВЕРХНЕГО КЕМБРИЯ ИЗ СКВАЖИНЫ М-72 СЕВЕРНОЙ ЭСТОНИИ}

Материал для настоящей работы был отобран из интервала $112,8-119,6$ м скважины М-72, расположенной в 30 км юго-восточнее Таллинна. Указанный интервал соответствует, согласно современным - представлениям, тситреской свите (Опорные разрезы..., 1989). Пять проб содержали однородный комплекс акритарх явно верхнекембрийского облика. На основе таких видов, как Trunculumarium revinium, Veryhachium dumontii, Leiofusa stoumonensis, Dasydiacrodium caudatum иं D. obsonum, можно коррелировать тситрескую свиту с зональной шкалой по трилобитам начиная с верхней части зоны Parabolina spinulosa до зоны Leptoplastus. включительно. Описано два новых вида - Cymatiogalea wironia sp. $\mathrm{n}$. и C. dentalea sp. $\mathrm{n}$. 